\title{
Funktionaalisten elintarvikkeiden hyväksyttävyys ja käyttö
}

\author{
Mari Niva, Johanna Mäkelä ja Sanna Piiroinen \\ Kuluttajatutkimuskeskus, PL 5,00531 Helsinki,mari.niva@kuluttajatutkimuskeskus.fi, \\ johanna.makela@kuluttajatutkimuskeskus.fi,sanna.piiroinen@kuluttajatutkimuskeskus.fi
}

\section{Johdanto}

Tieto ruoan ja terveyden välisistä yhteyksistä lisääntyy jatkuvasti, ja tutkimus kertoo yhä suuremmalla tarkkuudella ravinnon ainesosien ja terveyden osatekijöiden välisistä suhteista. Lisääntyvä tieto ja uudet teknologiat ovat mahdollistaneet uudenlaisten, terveysvaikutteisiksi kutsuttujen elintarvikkeiden kehittämisen ja markkinoinnin. Käsite terveysvaikutteinen tai funktionaalinen elintarvike onkin vähitellen vakiinnuttanut paikkansa keskustelussa ruoasta ja terveydestä. Uusia eri tavoin terveysvaikutteisina markkinoituja elintarvikkeita tulee lisääntyvässä määrin kauppojen hyllyille ja kuluttajien ulottuville. Terveysvaikutteisen elintarvikkeen käsitettä ei kuitenkaan ole määritelty lainsäädännössä, eivätkä asiantuntijatkaan ole yksimielisiä käsitteen rajauksista (Verschuren 2002).

Viime vuosina myös kuluttajatutkimusta terveysvaikutteisista elintarvikkeista on pidetty yhä tärkeämpänä. Kuluttajanäkemyksiä on tutkittu monenlaisin menetelmin ja lähestymistavoin. On tarkasteltu kuluttajien käsityksiä terveellisyyden tärkeydestä, terveysväitteiden ymmärtämistä ja niiden vaikutusta halukkuuteen käyttää terveysvaikutteisia tuotteita ja arvioitu esimerkiksi terveysvaikutteisten elintarvikkeiden makua aistinvaraisin testein. Laadulliset tutkimukset (Niva \& Jauho 1999; Niva ym. 2000) ovat myös viitanneet siihen, että terveysvaikutteisten elintarvikkeiden hyväksyttävyydessä voidaan erotella erilaisia näkökulmia. Näiden tutkimusten mukaan terveysvaikutteisten elintarvikkeiden käytön lisäksi hyväksyttävyyteen liittyvät laajemmin terveysvaikutteisuuden kehityssuuntaan liittyvät kysymykset, kuten luottamus uusiin tuotteisiin ja niitä kehittäviin ja valvoviin tahoihin, lääkkeen ja ruoan välinen vastakkainasettelu sekä näkemykset uusien tuotteiden teknologisuudesta ja luonnollisuudesta. Siihen kytkeytyy myös yhteiskunnallinen keskustelu ruoantuotannon suunnista ja syömisen kulttuureista (ks. myös Mäkelä 2002).

Tätä laajempaa näkökulmaa terveysvaikutteisiin elintarvikkeisiin olemme kutsuneet uusien tuotteiden kulttuuriseksi hyväksyttävyydeksi. Selvitimme yhtäl̈ltä terveysvaikutteisten tuotteiden käyttöä, toisaalta niiden kulttuurista hyväksyttävyyttä määrällisessä tutkimuksessa, joka toteutettiin Kuluttajatutkimuskeskuksessa vuosina 2001-2003 (ks. laajemmin Niva ym. 2003).

\section{Aineisto ja menetelmät}

Tutkimus toteutettiin kvantitatiivisena tutkimuksena, sillä kysymyksenasettelut edellyttivät tilastollista otetta. Aineisto kerättiin tietokoneavusteisina puhelinhaastatteluina keväällä 2002. Se on tilastollisesti edustava otos 15 vuotta täyttäneistä suomalaisista $(\mathrm{N}=1210)$. Aineistoa tarkasteltiin tilastollisin testein $\left(\chi^{2}\right.$-testi) sekä monimuuttujamenetelmin.

Kulttuurista hyväksyttävyyttä tutkimme siten, että vastaajia pyydettiin ottamaan kantaa terveysvaikutteisia elintarvikkeita koskeviin väittämiin. Vastaukset analysoitiin faktorianalyysin avulla. Faktoripisteitä käytettiin ryhmittelyanalyysissa, jonka avulla vastaajat jaettiin terveysvaikutteisiin elintarvikkeisiin eri tavoin suhtautuviin ryhmiin. Käytimme SPSS 11.5 -version TwoStepryhmittelyanalyysia, jossa ryhmien lukumäärän annettiin määräytyä analyysissa.

Terveysvaikutteisten tuotteiden käyttöä tutkimme kysymällä kymmenen erilaisen terveysvaikutteisena markkinoidun tuotteen tai tuoteperheen käytön useutta ja syitä. Esimerkkituotteet olivat Atrian Benecol-tuotteet, Benecol- tai Becel pro.aktiv -levitteet, Elovena Plus -kauralese- ja -hiutalesekoitus, Evolus hapatettu maitojuoma, Gefilus-tuotteet, Hyvää Päivää -juomat, ksylitolipurukumi, Linobene-tuotteet, Rela-tuotteet ja Yosa hapatettu kauralesevalmiste. Käyttöä selittäviä tekijöitä analysoimme tilastollisin testein ja logistisen regressioanalyysin avulla.

\section{Tulokset ja tulosten tarkastelu}

Terveysvaikutteisten elintarvikkeiden kulttuurinen hyväksyttävyys

Terveysvaikutteisten elintarvikkeiden kulttuurista hyväksyttävyyttä koskevan faktorianalyysin tuloksena saatiin ratkaisu, jossa terveysvaikutteisten elintarvikkeiden kulttuurista hyväksyttävyyttä käsittelevät muuttujat latautuivat neljälle faktorille (Taulukko 1). Ensimmäiselle faktorille latautui voimakkaasti 
muuttujia, jotka liittyivät vastaajien omiin kokemuksiin terveysvaikutteisista elintarvikkeista. Lisäksi yleisempää suhtautumista kuvaavat väitteet siitä, onko terveysvaikutteisten elintarvikkeiden lisääntyminen markkinoilla oikea kehityssuunta ja siitä, ovatko terveysvaikutteiset elintarvikkeet terveille ihmisille tarpeellisia, latautuivat voimakkaimmin tälle faktorille. Faktorille annettiin nimi omakohtainen kokemus ja usko terveysvaikutteisuuteen. Toisen, huolenaiheet-faktorin korkeimmin latautuneet muuttujat puolestaan liittyivät terveysvaikutteisten elintarvikkeiden käytön ja tarjonnan kielteisiin seurauksiin yleisesti syömiselle ja terveydelle sekä sopivuuteen lapsille. Kolmannen, turvallisuus ja laatu -faktorin kärkimuuttujat käsittelivät terveysvaikutteisten tuotteiden turvallisuutta ja laatua. Neljännen faktorin voimakkaimmin latautuneet muuttujat koskivat terveysvaikutteisten elintarvikkeiden ja niiden markkinoinnin valvontaa sekä tieteellistä näyttöä terveysvaikutuksista. Faktori nimettiin valvontafaktoriksi.

Analyysin tulos osoittaa, että terveysvaikutteisten elintarvikkeiden kulttuurisessa hyväksyttävyydessä voidaan erottaa erilaisia ulottuvuuksia. Yhtäältä kysymys on siitä, millaisia kokemuksia kuluttajilla on terveysvaikutteisista elintarvikkeista ja missä määrin terveysvaikutteisiin elintarvikkeisiin uskotaan terveyden ja hyvinvoinnin edistäjinä. Terveysvaikutteisia elintarvikkeita koskeva huolet - sopivatko tuotteet lapsille, voiko liiallinen käyttö olla terveydelle haitallista sekä mitä tuotteiden yleistyminen tarkoittaa yleisesti syömisen tavoille ja kulttuureille - muodostivat edellisestä, terveysvaikutteisia elintarvikkeita koskevasta uskosta ja kokemuksista erillisen ulottuvuuden. Tämä viittaa siihen, että kulttuurisessa hyväksyttävyydessä kokemusten suhde huoliin ei ole mitenkään yksiselitteinen. Hyviinkin kokemuksiin saattaa liittyä huolta ja epäilyjä esimerkiksi turvallisuudesta ja päinvastoin. Turvallisuuteen ja laatuun kytkeytyvät kysymykset latautuivat kuitenkin vielä erikseen omalle faktorilleen, joka voidaankin tulkita tieteen ja tutkimuksen pätevyyteen liittyvänä ulottuvuutena. Turvallisuuden ja riskien, vastuun ja luottamuksen moniulotteiseen suhteeseen kytkeytyy myös neljäs faktori, mutta jälleen eri näkökulmasta kuin edellä. Tämän faktorin väitteiden voi tulkita kertovan kuluttajien ja valmistajien välisen luottamuksen edellytyksistä: viranomaisten valvonta ja tuotteiden vaikutusten todentaminen tieteellisesti ovat eräänlaisia välittäjiä ja takaajia kuluttajien ja valmistajien välillä.

\section{Taulukko 1. Faktorianalyysi terveysvaikutteisten elintarvikkeiden kulttuurista hyväksyttävyyttä} koskevista muuttujista (pääakselifaktorointi, varimax-rotatointi).

\begin{tabular}{|c|c|c|c|c|c|}
\hline \multirow[b]{2}{*}{ Muuttuja } & \multicolumn{4}{|c|}{ Faktori } & \multirow[b]{2}{*}{$h^{2}$} \\
\hline & 1 & 2 & 3 & 4 & \\
\hline Terveysvaikutteiset elintarvikkeet ovat parantaneet hyvinvointiani. & ,720 &,- 072 & ,219 &,- 040 &, 572 \\
\hline Ihmiset olisivat terveempiä, jos he käyttäisivät enemmän terveysvaikutteisia elintarvikkeita. & ,668 &,- 208 & ,220 & ,035 &, 539 \\
\hline Terveysvaikutteisten elintarvikkeiden lisääntyminen markkinoilla on oikea kehityssuunta. &, 571 &,- 331 & ,339 & 116 &, 565 \\
\hline $\begin{array}{l}\text { Maksan mielelläni terveysvaikutteisista elintarvikkeista enemmän kuin tavallisista } \\
\text { elintarvikkeista. }\end{array}$ &, 531 &,- 090 & ,230 & ,071 & ,349 \\
\hline En osta terveysvaikutteisia elintarvikkeita. &,- 484 &, 263 &,- 173 &, 068 & ,338 \\
\hline Luotan, että terveysvaikutteiset elintarvikkeet vaikuttavat luvatulla tavalla. & ,480 &,- 134 & ,430 & ,009 & ,434 \\
\hline Terveille inmisille terveysvaikutteiset elintarvikkeet ovat tarpeettomia. &,- 469 & ,454 &,- 038 & 166 & ,454 \\
\hline Terveysvaikutteisia elintarvikkeita syömällä voi tuskin ehkäistä sairauksia. &,- 367 & ,293 &,- 003 & ,098 & ,230 \\
\hline Terveysvaikutteiset elintarvikkeet vievät syömistämme huonoon suuntaan. &,- 295 &, 573 &,- 193 &,- 023 & ,453 \\
\hline Uskon, että terveysvaikutteisten elintarvikkeiden liiallinen käyttö voi olla terveydelle haitallista. &,- 063 &, 562 &,- 156 & 179 & ,376 \\
\hline Terveysvaikutteiset elintarvikkeet eivät sovi lapsille. &,- 172 &, 550 &,- 081 & 112 & ,351 \\
\hline Uskon, että terveysvaikutteisten elintarvikkeiden turvallisuus on riittävän tarkasti tutkittu. & 170 &,- 200 & ,641 &,- 059 & ,483 \\
\hline Suomalaiset terveysvaikutteiset elintarvikkeet ovat korkealaatuisia. & ,280 &,- 087 &, 546 & ,116 & ,398 \\
\hline $\begin{array}{l}\text { Uskon terveysvaikutteisen elintarvikkeen vaikutukseen, jos lääkäri tai terveydenhoitaja } \\
\text { suosittelee sen käyttöä. }\end{array}$ & ,327 &,- 088 & ,401 & ,212 & ,321 \\
\hline Viranomaisten on valvottava erityisesti terveysvaikutteisten elintarvikkeiden markkinointia. & ,067 & 177 &, 045 & ,646 & ,456 \\
\hline $\begin{array}{l}\text { Terveysvaikutteisia elintarvikkeita ei mielestäni saisi tuoda markkinoille ilman viranomaisten } \\
\text { hyväksyntää. }\end{array}$ &,- 004 & ,083 &,- 011 & ,618 & ,388 \\
\hline $\begin{array}{l}\text { Terveysvaikutteisina markkinoitujen elintarvikkeiden vaikutusten pitää olla tieteellisesti } \\
\text { todistettuja. }\end{array}$ &,- 059 & ,032 & 075 &, 545 & ,308 \\
\hline & & & & & Yhteensä \\
\hline Ominaisarvo & 2,735 & 1,586 & 1,427 & 1,267 & 7,015 \\
\hline Selitysaste (varimax-rotaation jälkeen) & 16,089 & 9,330 & 8,395 & 7,455 & 41,268 \\
\hline Kaiser-Meyer-Olkin -mitta 0,893. & & & & & \\
\hline
\end{tabular}

Vastausvaihtoehtona oli viisiportainen Likert-asteikko, jossa 1 = täysin eri mieltä, 2 = jokseenkin eri mieltä, 3 = ei samaa eikä eri mieltä, 4 = jokseenkin samaa mieltä ja 5 = täysin samaa mieltä. 


\section{Kolme kuluttajaryhmää}

Faktorianalyysin kullekin havainnolle tuottamia faktoripistemääriä käyttämällä vastaajat jaettiin terveysvaikutteisiin elintarvikkeisiin kohdistuvan suhtautumisen perusteella erilaisiin ryhmiin. Analyysin tulokseksi saatiin kolme toisistaan poikkeavaa ryhmää, joita kuvaa erilainen suhtautuminen terveysvaikutteisiin elintarvikkeisiin omakohtaisten kokemusten ja huolenaiheiden sekä turvallisuutta, laatua ja valvontaa koskevien näkemysten suhteen. Ryhmille annettiin nimet luottavaiset, epäilevät ja huolettomat. (Taulukko 2.)

Taulukko 2. Klustereiden profiilit faktorin mukaan (standardoitujen faktoripistemuuttujien ryhmäkeskusten keskiarvot klustereissa).

\begin{tabular}{|l|c|c|c|}
\hline \multicolumn{2}{|c|}{ Klusteri } \\
\hline Faktori & \multicolumn{2}{|c|}{ epäilevät (N=393) } & huolettomat (N=345) \\
\hline omakohtainen kokemus ja usko terveysvaikutteisuuteen & luottavaiset $(\mathrm{N}=471)$ & $-0,817$ & 0,114 \\
\hline huolenaiheet & 0,598 & 0,437 & $-0,339$ \\
\hline turvallisuus ja laatu & $-0,116$ & $-0,289$ & $-0,033$ \\
\hline valvonta & 0,265 & 0,263 & $-0,975$ \\
\hline
\end{tabular}

Ensimmäistä ryhmää, luottavaisia, kuvaa positiivinen suhtautuminen terveysvaikutteisia elintarvikkeita kohtaan sekä luottamus ja usko näiden tuotteiden tarpeellisuuteen. He olivat terveysvaikutteisten elintarvikkeiden ostajia eivätkä he liittäneet niihin erityisiä huolenaiheita. He kokivat hyvinvointinsa parantuneen terveysvaikutteisten elintarvikkeiden ansiosta ja olivat sitä mieltä, että ihmiset olisivat terveempiä, jos he käyttäisivät enemmän terveysvaikutteisia elintarvikkeita. Toista ryhmää, epäileviä, luonnehtii melko kielteinen suhtautuminen terveysvaikutteisiin elintarvikkeisiin. Heidän mielestään terveille ihmisille terveysvaikutteiset elintarvikkeet ovat tarpeettomia eivätkä he uskoneet, että terveysvaikutteisten elintarvikkeiden käyttö tekisi ihmisistä terveempiä. He suhtautuivat epäuskoisesti siihen, että tuotteet vaikuttaisivat luvatulla tavalla ja uskoivat, että terveysvaikutteisten tuotteiden liiallinen käyttö voi kääntyä terveydelle haitalliseksi. Sekä luottavaiset että epäilevät korostivat viranomaisvalvonnan ja terveysvaikutusten tutkimuksen tärkeyttä. Huolettomat suhtautuivat melko neutraalisti terveysvaikutteisiin elintarvikkeisiin. Monessa suhteessa heidän näkemyksensä asettuivat luottavaisten ja epäilevien välimaastoon. Luottavaisten tapaan he pitivät terveysvaikutteisten elintarvikkeiden lisääntymistä oikeana kehityssuuntana ja ilmoittivat ostavansa terveysvaikutteisia elintarvikkeita. Heille tyypillistä oli, että viranomaisten hyväksyntää, markkinoinnin valvontaa ja vaikutusten tieteellistä todentamista pidettiin vähemmän tärkeänä kuin muissa ryhmissä. Ryhmillä oli osittain yhteisiä piirteitä. Luottavaisia ja huolettomia yhdisti yleinen myönteisyys terveysvaikutteisia elintarvikkeita kohtaan, luottavaisia ja epäilijöitä taas valvonnan ja säätelyn tärkeyden korostaminen. Toiseksi eroja oli valvontaa ja viranomaisten roolia koskevalla ulottuvuudella, jolla huolettomat poikkesivat muista.

Ryhmien koossa ei ollut suuria eroja. Luottavaisia oli kaikista vastaajista $39 \%$, ja se oli ryhmistä suurin. Epäileviin kuului $32 \%$ ja huolettomiin 29 \% vastaajista. Ryhmät olivat demografisesti varsin samankaltaisia ikää lukuun ottamatta. Luottavaisissa oli muita ryhmiä runsaammin yli 45 -vuotiaiata vastaajia, kun taas huolettomissa oli erityisesti nuoria, alle 30-vuotiaita. Käsitykset terveysvaikutteisista elintarvikkeista olivat jossain määrin kytköksissä ikään (ja sen myötä elämäntilanteeseen), mutta eivät esimerkiksi sukupuoleen, koulutukseen tai asuinpaikkaan.

\section{Terveysvaikutteisten elintarvikkeiden käyttö}

Terveysvaikutteisista elintarvikkeista useimmin käytettiin tuotteita, joiden terveysvaikutukset kohdistuvat hampaiden hyvinvointiin, vatsan ja suoliston hyvinvointiin ja veren kolesteroliin. Käytetyimpiä tuotteita olivat ksylitolipurukumi (79\% vastaajista oli käyttänyt viimeisen vuoden aikana), Gefilus-tuotteet (78 \%) ja Benecol- tai Becel pro.aktiv -levitteet (44 \%). Säännöllisesti (viikoittain tai lähes päivittäin) näitä kolmea tuotetta käytti vastaavasti $56 \%, 34 \%$ ja $17 \%$ vastaajista. Muiden tuotteiden säännöllinen käyttö oli näitä tuotteita huomattavasti vähäisempää. Kolmea käytetyintä tuotetta yhdistää toisiinsa ja erottaa muista tarkastelluista tuotteista pitkäaikainen terveysvaikutuksia koskeva tutkimus ja aktiivinen markkinointi. Ne ovat myös olleet kuluttajien saatavilla pidempään kuin useimmat muut tutkimuksen esimerkkituotteet.

Erilaisten terveysvaikutteisten tuotteiden käyttäjät olivat erilaisia. Monet taustamuuttujat, kuten ikä, koulutus ja ammattiasema näyttäytyivät hieman eri tavoin tarkasteltaessa eri tuotteiden käyttöä. Käytöllä oli kuitenkin paljon yhteisiä piirteitä. Logististen regressiomallien perusteella voidaan sanoa, että 
yleensä naiset käyttivät terveysvaikutteisia elintarvikkeita todennäköisemmin kuin miehet, iäkkäät todennäköisemmin kuin nuoret, koulutetut todennäköisemmin kuin vähän koulutusta saaneet ja korkeassa ammatillisessa asemassa olevat todennäköisemmin kuin ne, jotka olivat työelämän ulkopuolella. Poikkeuksia olivat kuitenkin ksylitolipurukumi, jota nuoret käyttivät iäkkäitä todennäköisemmin sekä kolesterolia alentavat levitteet, jotka olivat enemmän miesten suosiossa kuin naisten. Tämä liittynee siihen, että naisilla on - kuten monet tutkimukset ovat osoittaneet - miehiä selvempi yleinen pyrkimys syödä ja elää terveellisesti. Voikin olla, että miehillä terveysvaikutteisten tuotteiden käyttö liittyy enemmän johonkin tunnistettuun ongelmaan. Myös pyrkimys edistää terveyttä joko liikuntaa harrastamalla, erilaisia ravintolisiä käyttämällä tai veren kolesterolia alentamalla lisäsivät todennäköisyyttä käyttää terveysvaikutteisia elintarvikkeita. Mikään näistä muuttujista ei kuitenkaan yltänyt merkitseväksi selittäjäksi kaikissa malleissa, mikä kertoo siitä, että eri tuotteita käyttivät erilaiset kuluttajat. Ainoastaan suhtautuminen terveysvaikutteisiin elintarvikkeisiin näyttää olevan tekijä, joka selittää kolmen eniten käytetyn tuotteen käyttöä samansuuntaisesti. Myönteisesti suhtautuvat käyttivät tuotteita todennäköisemmin kuin kielteisemmin suhtautuvat.

\section{Johtopäätökset}

Terveysvaikutteisten elintarvikkeiden kulttuurinen hyväksyttävyys on moniulotteinen kokonaisuus. Kuluttajilla on erilaisia tapoja suhtautua terveysvaikutteisiin elintarvikkeisiin, ja suhtautumisessa korostuvat erilaiset asiat. Kulttuurinen hyväksyttävyys kietoutuu myös terveysvaikutteisina markkinoitujen tuotteiden käyttöön, mutta yhteys ei ole aivan yksiselitteinen. Eri tavoin painottuneesta suhtautumisestaan huolimatta sekä myönteisesti että neutraalisti suhtautuvat ovat terveysvaikutteisten elintarvikkeiden käyttäjiä ja eroavat siten epäilevistä, jotka käyttävät tuotteita huomattavasti harvemmin.

Terveysvaikutteisten elintarvikkeiden idea, kehittäminen, markkinointi ja suosio voidaan nähdä osana kehitystä, jossa terveys ja elämäntapojen terveellisyys saavat yhä uusia merkityksiä. Ravitsemusvalistuksen kulmakivi on jo jonkin aikaa ollut ruokavalion kokonaisuuden, monipuolisuuden, tasapainoisuuden ja kohtuullisuuden korostaminen. Terveysvaikutteisten tuotteiden idean sovittaminen yhteen valistuksen painottamien tekijöiden kanssa on haasteellista. Uusilla tuotteilla luvataan olevan erityisiä, kohdennettuja terveysvaikutuksia, ja tiettyjä tuotteita käyttämällä voi lupausten mukaan edistää terveyttä ja vähentää sairauksien riskiä. Ei ole aivan yksinkertaista sovittaa yhteen vanha ajatus terveellisestä syömisestä ruokavalion kokonaisuutena ja täsmäterveellisyys, jota uudet erityiset terveysvaikutteiset elintarvikkeet edustavat.

Kulttuurisen hyväksyttävyyden ideaan kuuluu, että se muokkaantuu ajallisesti ja paikallisesti. Se muotoutuu osana monentasoisia ruokaa, terveyttä ja teknologiaa koskevia yhteiskuntamme ilmiöitä. Siksi sen muutosten ennustaminen on vaikeaa. Käsityksemme terveellisestä syömisestä muuttuvat koko ajan, ja uudet tuotteet vaikuttavat käsityksiimme siitä, mitä on terveellinen syöminen. Tiedämme yhä enemmän ravinnon ja terveyden välisistä yhteyksistä, mutta samalla valintojen tekeminen jatkuvasti monimutkaistuu. Tieto pirstaloituu ja yksityiskohtaistuu, ja kokonaiskuvan jäsentäminen siitä on yhä vaikeampaa.

Tutkimuksemme tulokset antavat aihetta pohtia, miten uudet terveysvaikutteiset elintarvikkeet muuttavat arkipäivän syömistämme ja käsityksiämme terveellisyydestä ja terveellisestä ruoasta. Uudet elintarvikkeet tulevat hyväksytyiksi vain asettumalla luontevasti osaksi arkisia ruokatottumuksia, muuten ne jäävät vaille hyväksyntää. Uusien elintarvikkeiden hyväksyttävyyteen liittyy kuitenkin myös laajempi, kulttuurinen ulottuvuus: keskustelu ruoantuotannon suuntauksista ja ravitsemus-, elintarvike- ja kuluttajapolitiikasta, terveellisyyden merkityksistä ja erityisesti tulevaisuudessa erilaisten teknologioiden hyväksyttävyydestä.

\section{Kirjallisuus}

Niva, M. \& Jauho, M. 1999. Ruoan ja lääkkeen välimaastossa. Funktionaalisia elintarvikkeista koskevat käsitykset ja julkinen keskustelu. Kuluttajatutkimuskeskuksen Julkaisuja 2/1999. Helsinki.

Niva, M., Timonen, P., Ryhänen, E.-L. \& Lähteenmäki, L. 2000. Kuluttaja ja tulevaisuuden terveysvaikutteiset elintarvikkeet - kaalia syövän ehkäisyyn tai maitoa stressiin? Kuluttajatutkimuskeskuksen Työselosteita ja esitelmiä 59/2000. Helsinki.

Niva, M., Mäkelä, J. \& Piiroinen, S. 2003. Kotimaisia marjoja ja kasvistanoleja. Terveysvaikutteisten elintarvikkeiden hyväksyttävyys Suomessa. Kuluttajatutkimuskeskuksen Julkaisuja 9/2003.

Verschuren, P. M. 2002. Summary report. Functional foods: scientific and global perspectives. British Journal of Nutrition 88 (Suppl. 2): S125-S130. 